\title{
Impact of Pseudomonas aeruginosa MAJ PIA03 affecting the growth and phytonutrient production of castor, a primary host-plant of Samia ricini
}

\author{
Sosanka Protim Sandilya ${ }^{1}$, Pinky Moni Bhuyan ${ }^{1}$, Vijay Nageshappa ${ }^{1}$, Dip Kumar Gogoi ${ }^{*}$, \\ Devid Kardong ${ }^{2}$
}

${ }^{1}$ Biotechnology Division, Central Muga Eri Research \& Training Institute, Central Silk Board, Lahdoigarh, Jorhat-785700, Assam, India. ${ }^{2}$ Department of Life Sciences, Dibrugarh University, Dibrugarh-786004, Assam, India. *Corresponding author: gkdeep@rediffmail.com

\begin{abstract}
Castor (Ricinus communis L.) is a primary food plant of eri silkworm, Samia ricini Donovan endemic to Northeast India. Plant growth promoting rhizobacteria (PGPR) plays crucial role in growth and productivity of agricultural crops. Eighty-five Pseudomonas strains were isolated from thirty rhizosphere soil samples of castor and their in vitro potentiality was screened for growth promoting ability and antifungal potentialities. Most of the selected Pseudomonas sp. produced indole acetic acid, gibberellic acid, ACC deaminase activity, ammonia, hydrogen cyanide and siderophore, when tested in-vitro for PGP activity. Besides, the strains MAJ PIA01, MAJ PIA03 and MAJ PIA24 have got antifungal activity against five common plant pathogens. Upon their formulation and application in field by curtailing the recommended dose of inorganic fertilizers to $50 \%$, isolate no. MAJ PIA03 efficiently enhanced the agronomical traits such as number of leaves per plant, leaf biomass, root length, stem base diameter, shoot length, root biomass and leaf moisture content. Isolate no. MAJ PIA03 has significant impact on leaf biochemical constituents and augments the nutritional quality of castor leaf. The most efficient isolate MAJ PIA03 was identified as Pseudomonas aeruginosa MAJ PIA03 by polyphasic approach and its 16S rRNA gene homology. The bio-formulation of Pseudomonas aeruginosa MAJ PIA03 with $50 \%$ diminution on recommended inorganic NPK dose could be used as an effective mechanism to improve Ricinus communis plant growth as well as leaf nutritional enhancement for sustainable eri sericulture.
\end{abstract}

Keywords: Plant growth promoting rhizobacteria, Pseudomonas sp., Ricinus communis, Samia ricini, Sericulture 


\section{Introduction}

Castor (Ricinus communis L.) belonging to the family Euphorbiaceae is an annual or perennial herb which is being utilized as a primary host/food plant by the multivoltine sericigenous insect Samia ricini Donovan (eri silkworm). Eri culture is a small scale textile industry endemic to the Northeastern states of India and has been a prime source of income among the people of this region since immemorial time (Sandilya et al., 2016). It is mainly concerned with the production of commercial silk and warm cloth and the production parameter lies mostly on the consumption of quality leaves. Sericulture farmers of Northeast region mostly opt for the inorganic fertilizers for years resulting in deterioration of agricultural soil quality. Since the yield reduction is a vital problem in organic farming (Lind et al., 2003), the integrated nutrient management (INM) with reduced chemical doses may boost the quality leaf yield for commercial silkworm rearing. Strategic implementation of INM practices lead to eco-friendly, sustainable and organic agricultural practice (Esitken et al., 2005).

Plant growth promoting rhizobacteria (PGPR) is a heterogeneous group of bacteria that originates mainly in the rhizosphere, at root surfaces or in symbiotic association with roots. Enormous diversity of rhizobacteria such as Agrobacterium, Alcaligenes, Arthrobacter, Azospirilium, Azotobacter, Bacillus, Beijerinckia, Burkholderia, Clostridium, Enterobacter, Klebsiella, Phyllobacterium, Pseudomonas, Rhizobium, Serratia, Vario-vovax, Xanthomonas, etc. has been reported over the years (Glick et al., 2004). The impact of rhizobacteria on plant nutrition and growth enhancement is manifold. Multiple mechanisms of PGPR action could promote sustainable plant development as it has got direct effect on the enhancement of plant growth; either by synthesizing growth promoting substances, or facilitating nutrients uptake from environment (Viscardi et al., 2016).
Fluorescent Pseudomonads are aerobic, gram-negative bacteria, ubiquitous in agricultural soils and are well adapted to grow in the rhizosphere. Pseudomonads possess the ability to colonize and multiply in the rhizosphere and intercellular spaces of plant tissue and produce a wide spectrum of bioactive metabolites such as antibiotics, siderophore, HCN and growth promoting substances (Weller 2007). They can suppress pathogenic toxicity by producing specific antibiotics and siderophores to induce systemic resistance to the host (Dwivedi and Johri 2003). Pseudomonads also play a decisive role in plant growth promotion through reduction of ethylene production by synthesizing 1-aminocyclopropane-1-carboxylate (ACC) deaminase. The ACC deaminase enzyme modulates the level of ethylene by hydrolyzing ACC in ammonia and $\alpha$-ketobutyrate (Marques et al., 2010). Pseudomonas fluorescens strain Psd solubilizes inorganic zinc and produces nitrate reductase along with certain antioxidant enzymes such as glutathione reductase and peroxidase which eventually supports the growth of wheat (Sirohi et al., 2015).

Reports on the exploitation of beneficial rhizobacteria for sustainable host plant cultivation in sericulture sector are very sporadic. Therefore, characterization and introduction of native potential Plant Growth Promoting Rhizobacteria (PGPR) may help in enrichment of soil nutrients and thereby increase quality castor leaf yield for eri silkworm rearing $(\mathrm{Ku}-$ mar et al,. 2012). In the present study, an effort has been made to: (i) determine the quantitative growth promoting activity of Pseudomonads, isolated from castor rhizosphere, (ii) assess the impact of Pseudomonads affecting the growth and leaf biochemical constituents of the target crop and (iii) identify the most efficient isolate by polyphasic approach. 


\section{Materials and Methods}

\subsection{Isolation of pseudomonads}

Pseudomonads were isolated from rhizosphere soil of castor plants collected from natural habitats of upper Assam, India. Samples were collected from Garmur satra (26.96873 oN 94.14370. oE), Kamalabari satra (26.94356 oN $94.20002 \mathrm{oE}$ ) and bank of river Brahmaputra (26.92356 oN $94.24210 \mathrm{oE}$ ) of Majuli river island, Assam with an elevation of 87.3, 89.2 and 84.3 $\mathrm{m}$ respectively. Sterile poly bags were used to carry the samples aseptically to the laboratory, further stored at $4{ }^{\circ} \mathrm{C}$ and processed within 24 hours for analysis. Isolation was carried out by serial dilution spread plate technique (Buchanan \& Gibbon, 1974) using Pseudomonas Isolation Agar (PIA) medium (Hi-media Ltd., Mumbai). Soil sample was suspended in sterile saline solution $(0.80 \% \mathrm{NaCl})$ serially diluted up to $10^{-7}$ and inoculated on PIA medium at $\mathrm{pH} 6.8$ and incubated at $32{ }^{\circ} \mathrm{C}$ (OVFU, O-CIS-4D). Pseudomonas colonies were selected based on the visual colony morphology and colours were further purified by subsequent culturing. Sub-cultured pure cultures were preserved at $-80{ }^{\circ} \mathrm{C}$ in Luria Broth (LB) supplemented with $15 \%$ glycerol for further study.

\subsection{Morphological and biochemical characterization}

Cultural characters of the pure isolates were studied on the basis of colony elevation, margin, form, texture and opacity. The morphological study was conducted by Gram staining microscopy method using Gram staining kit (Hi-media K001) (Holt et al., 1994). The stained bacterial cells were observed under Phase contrast microscope (Olympus, CKX41) to monitor the Gram reaction, shape, orientation, etc. Biochemical characterization was carried out through culture dependent techniques as per the Bergey's Manual of
Determinative Bacteriology and using Biochemical Test Kit (Hi-media Ltd., Mumbai, India).

\subsection{In vitro screening for PGP traits}

2.3.1. Assay for Indole acetic acid (IAA)

IAA production by Pseudomonas isolates was estimated by little modification of the method described by Wohler (1997). The bacteria were cultured for 24 hours on nutrient broth and centrifuged at $14000 \mathrm{rpm}$ for 5 minutes to collect the cells. The cell pellets were incubated at $37{ }^{\circ} \mathrm{C}$ for $24 \mathrm{~h}$ after suspending in 3.0 $\mathrm{mL}$ of phosphate buffer ( $\mathrm{pH} 7.5$ ) containing glucose (1\%) and tryptophan (1\%). After incubation, $2.0 \mathrm{~mL}$ of $5 \%$ trichloroacetic acid and $1.0 \mathrm{~mL}$ of $0.5 \mathrm{M} \mathrm{CaCl}_{2}$ were added and filtered through Whatman paper no. 2. Salper solution $(2.0 \mathrm{~mL})$ was added to $3.0 \mathrm{~mL}$ of the filtrates taken in test tubes. The reaction mixture was then incubated at $28{ }^{\circ} \mathrm{C}$ for 30 minutes in dark condition. The absorbance was measured at $535 \mathrm{~nm}$ using UV-vis spectrophotometer (Systronics 2202) and concentration of IAA (mg L $\left.\mathrm{L}^{-1}\right)$ was calculated by calibrating with a standard curve made by using graded concentration of IAA.

\subsubsection{Assay for Gibberellic acid (GA3)}

GA3 production was measured as per Paleg (1965). $3.0 \mathrm{~mL}$ of culture filtrate obtained by the above method for IAA test was taken in test tube and added 2.0 $\mathrm{mL}$ of zinc acetate. Potassium ferrocyanide $(2.0 \mathrm{~mL})$ was then added after 2 minutes and centrifuged for 5 min at $1000 \mathrm{rpm}$. Finally, $5.0 \mathrm{~mL}$ of $30 \% \mathrm{HCl}$ was added to $5.0 \mathrm{~mL}$ of the supernatant and incubated at 20 ${ }^{\circ} \mathrm{C}$ for 2 hours and the colour intensity of the samples was measured at $254 \mathrm{~nm}$ using uv-vis spectrophotometer. GA3 concentration $\left(\mathrm{mg} \mathrm{L}^{-1}\right)$ was determined by 
calibrating with the standard curve of authentic GA3 (Hi-media Ltd., Mumbai).

\subsubsection{Assay for ACC deaminase}

For ACC deaminase activity of the Pseudomonas isolates, the broth culture was centrifuged at 10,000 rpm for $5 \mathrm{~min}$ and the resultant pellets were suspended in $5.0 \mathrm{~mL}$ of $0.1 \mathrm{~mol} \mathrm{~L}^{-1}$ of Tris $\mathrm{HCl}$ having $\mathrm{pH}$ 7.6. The solution is then centrifuged at $16,000 \mathrm{rpm}$ for $5 \mathrm{~min}$ utes and the cell pellets were re-poised in $2.0 \mathrm{~mL}$ of $0.1 \mathrm{~mol} \mathrm{~L}^{-1}$ Tris $\mathrm{HCl}(\mathrm{pH}$ 8.5). The cell suspension was vortexed for $1 \mathrm{~min}$ after the addition of $30 \mu \mathrm{L}$ of Toluene. Thereafter, $200 \mu \mathrm{L}$ of the whole mixture were placed in microcentrifuge tubes and supplemented with $20 \mu \mathrm{L}$ of $0.5 \mathrm{~mol} \mathrm{~L}^{-1} 1$ - aminocyclopropane1-carboxylate (ACC). The mixture was then vortexed and incubated for $15 \mathrm{~min}$ at $30^{\circ} \mathrm{C}$. After incubation, $1.0 \mathrm{~mL}$ of $0.56 \mathrm{~mol} \mathrm{~L}^{-1} \mathrm{HCl}$ was added to the solution and centrifuged at $16,000 \mathrm{rpm}$ for 5 minutes at $32{ }^{\circ} \mathrm{C}$. The resultant supernatant was then again mixed with $1.0 \mathrm{~mL}$ of $0.56 \mathrm{~mol} \mathrm{~L}^{-1} \mathrm{HCl}$, then vortexed and added $2.0 \mathrm{~mL}$ of 2, 4-dinitrophenylhydrazine reagent and incubated at $30{ }^{\circ} \mathrm{C}$ for 30 minutes. The entire suspension was then boosted with $2.0 \mathrm{~mL}$ of $2 \mathrm{~mol} \mathrm{~L}^{-1} \mathrm{NaOH}$ and the absorbance was recorded at $540 \mathrm{~nm}$. ACC deaminase activity was measured by calibrating with a standard curve prepared from serial concentrations of $\alpha$-ketobutyrate (TCI Chemicals).

\subsection{4. $\mathrm{NH}_{3}, \mathrm{HCN}$ and Siderophore production}

NH3 production was determined by inoculating the pure Pseudomonas isolates into $10 \mathrm{~mL}$ of peptone water and incubated for $48 \mathrm{~h}$ at $32{ }^{\circ} \mathrm{C}$. After incubation, $0.5 \mathrm{~mL}$ of Nessler's reagent was added to each tube. Appearance of yellow to brown colour indicates positive ammonia production by the isolates (Cappuccino and Sherman 1992).

\subsubsection{Antifungal assay}

Pseudomonas isolates were cultured on Nutrient broth medium for $48 \mathrm{~h}$ at $32{ }^{\circ} \mathrm{C}$ in orbital shaking incubator. The crude bioactive molecule was isolated from the culture broth by solvent extraction method using ethyl acetate in the ratio of 1:1 (Bordoloi et al., 2001). The solvent part was collected by using a separating funnel and evaporated in-vacuo to recover the crude extract. The crude extract was dissolved $\left(0.5 \mathrm{mg} \mathrm{mL}^{-1}\right)$ in dimethyl sulfoxide (DMSO) and antifungal bioassay was carried out by Agar well diffusion method (Grammer 1976) against five plant pathogenic fungi viz, Fusarium monoliformes, Fusarium oxysporum, Fusarium oxysporum f. sp. ciceri, Rhizoctonia solani and Fusarium glycopersicum. The antifungal activity was evaluated by measuring the growth inhibition zone against test fungi.

\subsection{Formulation of pseudomonas cultures}

Based on the plant growth promoting efficiency, the Pseudomonas isolates were selected and mass cultured in nutrient broth for field experiment. Formulation of the Pseudomonas cultures has been prepared in carrier material, as in vermicompost and inert material (i.e., Charcoal) in 1:1 ratio with final microbial load of 108 colony forming units (CFU). Eight treatment combinations were formulated out of selected Pseudomonas strains for field experiment.

\subsection{Cultivation of R. communis - experimental design}

$R$. communis NBR-1 seeds were surface sterilized with $0.5 \%(\mathrm{v} / \mathrm{v}) \mathrm{NaOCl}$ for 10 minutes and washed with sterile distilled water. Treated seeds were sown in RBD (Randomized block design) on the experimental plot as per the recommendation of CMERTI, Central Silk Board, Ministry of Textiles, Govt. of 
India, Assam (India). Input of recommended farm yard manure (FYM) i.e. NPK (urea: SSP: MOP $=13$ g: 25 g: 3 g per plant) and organic manure i.e. cowdung (1 kg plant $\left.{ }^{-1}\right)$ was taken as control. The pits were inoculated with Pseudomonas sp. (8 strains) formulations $\left(0.5 \mathrm{~kg}\right.$ plant $\left.^{-1}\right)$ with $50 \%$ reduction in recommended NPK dose. Simultaneously, $0.5 \mathrm{~kg}$ plant $^{-1}$ of organic manure (cow-dung) was also supplemented in each pit. Castor plants were maintained through routine cultural operation during the growth period and harvesting occurred 14 weeks after the experimental cultivation.

\subsection{Assessment of plant growth parameter}

Different plant growth parameters such as number of leaves, leaf weight (fresh), stem base diameter, root length, leaf biomass, leaf moisture content and percentage of leaf biomass increase over control was studied to assess the most efficient treatment combination for growth of castor plant.

\subsection{Assessment of Leaf biochemical constituents}

Total carbohydrate content (\%) was estimated by Anthrone method (Sadasivam and Manickam 2005). The method described by Lowry et al. (1951) was employed to determine the total soluble protein (\%). Lipid content (\%) of the leaf samples was ascertained by solvent extraction method using petroleum ether (Sadasivam and Manickam 2005). Phenol content was estimated by the method of Price and Butler (1975), whereas chlorophyll content (\%) in castor leaves was resolved by following standard protocol (Arnon 1949). Crude fiber content was estimated as per the method of AOAC (Association of Official Agricultural Chemist, USA).

\subsection{Molecular identification}

Molecular identification of the most potential isolate was carried out by 16S rDNA homology analysis. Isolation of the genomic DNA of the potential Pseudomonas strain was done by standard methodology (Marmur 1961) by using Genomic DNA extraction kit manufactured by SRL Pvt. Ltd., Mumbai (India). The DNA purity and quantity were checked by spectrophotometer at 260 and $280 \mathrm{~nm}$. PCR amplification of 16S rDNA was done with bacterial universal forward primer 16SF and reverse primer 16SR as described by Weisberg et al. (1991). The PCR for the 16S rRNA gene was performed with initial denaturation at $95^{\circ} \mathrm{C}$ for 2 min followed by 35 cycles consisting of $95^{\circ} \mathrm{C}$ for $1 \mathrm{~min}, 55^{\circ} \mathrm{C}$ for $1 \mathrm{~min}$ and $72{ }^{\circ} \mathrm{C}$ for $1.5 \mathrm{~min}$, followed by a final extension of $5 \mathrm{~min}$ at $72^{\circ} \mathrm{C}$. The PCR products were purified by using a QIA quick PCR purification kit (Qiagen) according to the manufacturer's instructions. The partial sequencing of the $16 \mathrm{~S}$ rDNA gene was carried out through the courtesy of DNA sequencing service, Merck Millipore (Bangalore GeNeiTM), Bangalore, India by using the same primer. The partial 16S rDNA gene sequence was aligned against representative reference sequences of the most closely related members obtained from the National Center for Biotechnology Information (NCBI) database (http://www.ncbi.nlm.nih.gov/BLAST). A neighbor joining phylogenetic tree was constructed in bioinformatics software programme MEGA 6.0 by multiple alignments using CLUSTALW (Saitou and Nie 1987). The identified gene sequence was submitted to NCBI GenBank and accession number was obtained.

\subsection{Statistical analysis}

The field experiment was designed in RBD with eight different treatments of Pseudomonas sps. and controls. Data were recorded as arithmetic mean of three 
independent replications for each treatment. Statistical analysis was performed by using the SPSS programme, version 16.0 through analysis of variance (ANOVA). Statistical significance of differences $(p<0.05$ and $p<0.01)$ was determined by Duncan's multiple range test (DMRT). Standard error means (SEM), critical difference (CD at 5\% level) and correlations were performed with different variables and Spearman's correlation coefficients were determined.

\section{Results}

\subsection{Isolation and characterization}

Eighty five pure culture of rhizobacteria were isolated from the thirty soil samples collected from various localities. Total viable colony count of Pseudomonas sp on PIA medium was highest $\left(2.4 \times 10^{3} \mathrm{CFU} / \mathrm{mL}\right)$ in the soil samples of Garmur satra, Majuli, Assam.

All the isolates were found to be gram negative rod of different sizes and texture. Characterization of the isolates resulted varied biochemical properties as per Bergey's Manual of Determinative Bacteriology (Holt et al., 1994).

\subsection{Microbial screening and bio-assay}

Based on the qualitative screening for plant growth promoting (PGP) activity and antifungal property, eight Pseudomonas isolates were selected for further analysis. Qualitative screening revealed that six Pseudomonas isolates have got $\mathrm{HCN}$ production ability and all the isolates synthesized $\mathrm{NH}_{3}$ in-vitro, whereas most of the Pseudomonads except MAJ PIA02 and MAJ PIA66 were capable of siderophore production (Table 1).

Table 1. Production of $\mathrm{NH}_{3}, \mathrm{HCN}$, Siderophore and antifungal activity of Pseudomonads against five plant pathogens

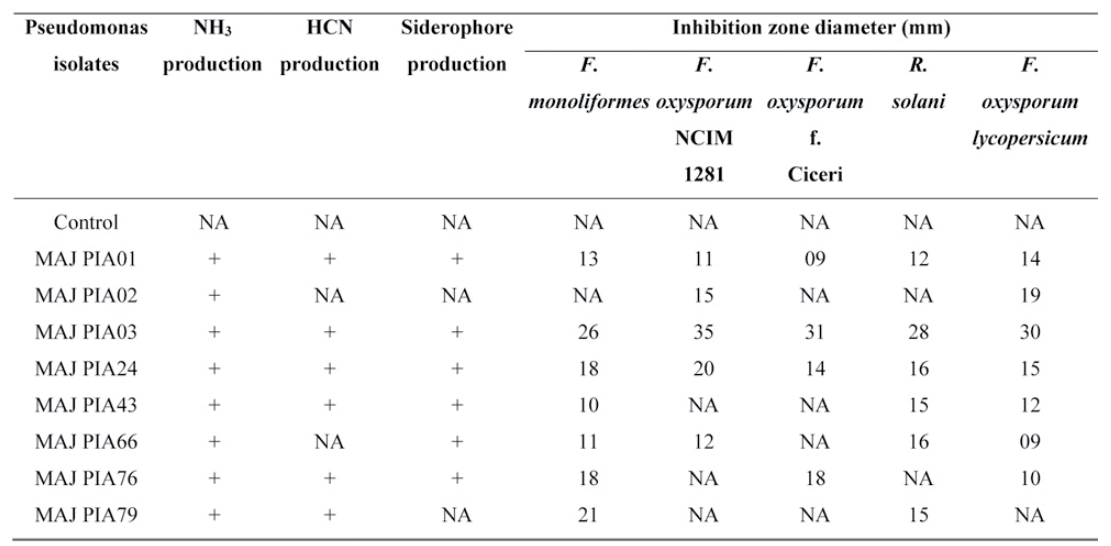

*NA: No activity; '+’: Positive activity; Numericals: Inhibition zone diameter in mm 
In-vitro antimicrobial bioassay result showed that MAJ PIA03 has produced inhibition zone diameter against five common plant pathogens viz., Fusarium monoliformes (26 mm), Fusarium oxysporum (35 $\mathrm{mm})$, Fusarium oxysporum Ciceri (31 mm), Rhizoctonia solani $(28 \mathrm{~mm})$ and Fusarium glycopersicum (30 mm) (Table 1).

IAA production by the Pseudomonas isolates was ranged between $5.19 \pm 1.29 \mathrm{mg} / \mathrm{L}$ to $27.84 \pm 0.52$ $\mathrm{mg} / \mathrm{L}$. Highest amount of IAA was produced by MAJ PIA03 (27.84 $\pm 0.52 \mathrm{mg} / \mathrm{L})$ whereas, lowest was recorded in MAJ PIA79 $(5.19 \pm 1.29 \mathrm{mg} / \mathrm{L})$. Production of IAA among the eight Pseudomonas isolates could be translated by the expression MAJ PIA03 $>$ MAJ PIA76>MAJ PIA24>MAJ PIA66 $>$ MAJ PIA43 $>$ MAJ PIA02>MAJ PIA01>MAJ PIA79 (Figure 1). Similarly, MAJ PIA03 synthesized maximum $(8.21 \pm 0.15$ $\mathrm{mg} / \mathrm{L}$ ) amount of $\mathrm{GA}_{3}$ and it was minimum in MAJ
PIA02 $(1.3 \pm 0.23 \mathrm{mg} / \mathrm{L})$. Isolate no. MAJ PIA76 $(5.88 \pm 0.14 \mathrm{mg} / \mathrm{L})$ showed substantial production of $\mathrm{GA}_{3}$ as compared to MAJ PIA03 (Figure 1). The translation of GA3 production by the Pseudomonads could be expressed as MAJ PIA03 $>$ MAJ PIA76 $>$ MAJ PIA79 $>$ MAJ PIA01 $>$ MAJ PIA66 $>$ MAJ PIA43 $>$ MAJ PIA24>MAJ PIA02.

Out of the eight Pseudomonads, six isolates have the ability to degrade ACC into $\alpha$-ketobutyrate. Highest ACC deaminase activity $(0.84 \mu \mathrm{g} / 10 \mathrm{~mL} / \mathrm{h})$ was recorded in MAJ PIA03, followed by MAJ PIA01 (0.66 $\mu \mathrm{g} / 10 \mathrm{~mL} / \mathrm{h}$ ) (Figure 2). Castor leaf and root biomass is positively correlated with synthesis of IAA, GA3 and ACC deaminase by Pseudomonads. Enhancement of these plant traits, particularly leaf biomass is significantly correlated $(p<0.05)$ with the production of IAA. On the contrary, leaf biomass was negatively correlated to ACC deaminase activity of the isolates.

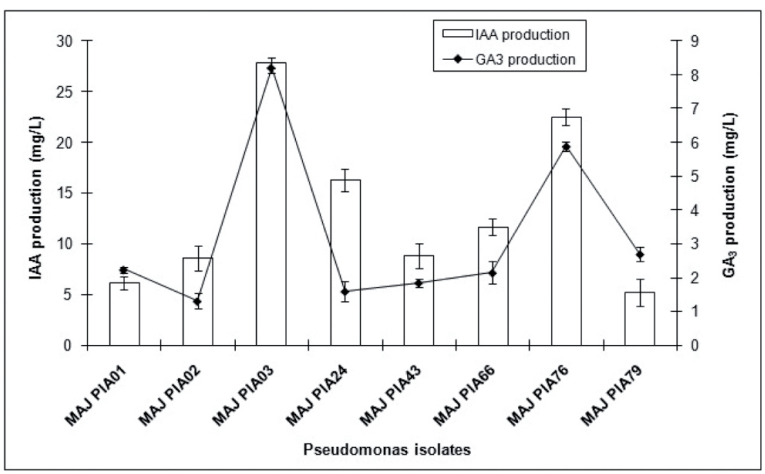

Figure 1. Production of IAA and $\mathrm{GA}_{3}(\mathrm{mg} / \mathrm{l})$ by Pseudomonas isolates. 


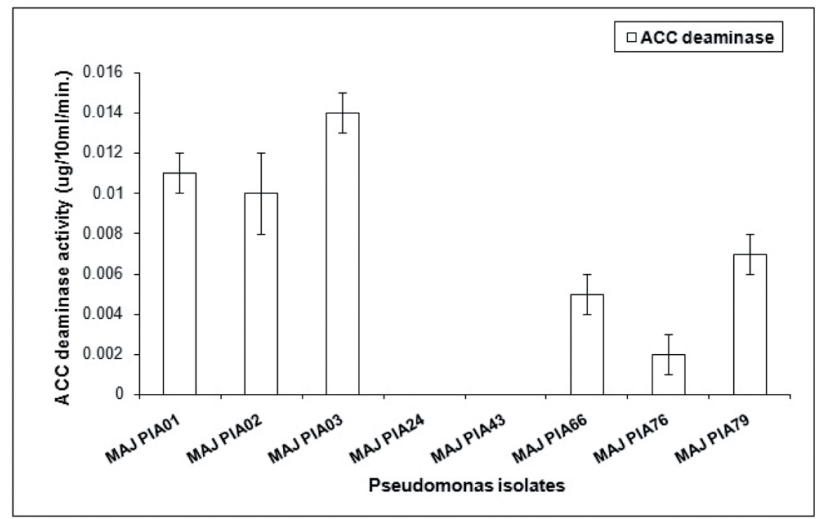

Figure 2. ACC deaminase activity $(\mu \mathrm{g} / 10 \mathrm{ml} / \mathrm{min}$.) of the Pseudomonas isolates.

\subsection{Growth parameter analysis}

Field trial under optimum growing conditions was conducted and significant enhancement $(\mathrm{P}<0.05)$ in growth and yield over control was recorded in the castor plants treated with Pseudomonas isolates and 50\% reduced dose of inorganic NPK. Highest leaf number $(49.40 \pm 7.28$ nos.), fresh leaf weight $(396 \pm 63.80 \mathrm{~g})$, root length $(59.60 \pm 1.92 \mathrm{~cm})$, root biomass $(55.10$ $\pm 11.24 \mathrm{~g})$, plant length $(260 \pm 19 \mathrm{~cm})$, leaf biomass $(97.60 \pm 5.47 \mathrm{~g})$ and leaf moisture content $(354.90 \pm$ $51.13 \mathrm{~g}$ ) was recorded in treatment $\mathrm{T} 5$.

The shoot elongation ranged from a minimum $1.72 \mathrm{~m}$ $(\mathrm{T} 4)$ to a maximum of $2.60 \mathrm{~m}$ when inoculated with T6. Similarly, root length of the plants were varied from $30.40 \mathrm{~cm}\left(\mathrm{~T}_{3}\right)$ to $59.60 \mathrm{~cm}\left(\mathrm{~T}_{5}\right)$ and most of the treatment promoted root growth significantly $(\mathrm{P}<$ $0.05)$ in comparison to untreated plants with an exception to $\mathrm{T}_{2}, \mathrm{~T}_{3}, \mathrm{~T}_{7}$ and $\mathrm{T}_{9}$ (Table 2).
Result indicated significant increase in shoot length $(260 \pm 19 \mathrm{~cm})$ over control in treatment $\mathrm{T} 6$, whereas, biomass per leaf increase over control (47.65 \%) was found maximum in treatment $T_{5}$. The average percentage biomass increase was $47.65 \%, 38.57 \%$ and 26.77 $\%$ when isolate nos. MAJ PIA03, MAJ PIA66 and MAJ PIA24 were applied, respectively (Table 2). Similarly, significant difference was observed in stem base diameter of castor treated with different combinations in comparison to control. The critical differences, standard error and significance at different confidence level among the variables are mentioned in Table 2 .

Inoculation of Pseudomonads treatment combinations influenced on the root and leaf biomass production of $R$. communis. The leaf dry biomass of $R$. communis varied from $60.40 \mathrm{~g}$ to $97.60 \mathrm{~g}$ where all the treatment combinations contributed significantly $(p<0.05)$ against the control. However, treatment T5 $(97.60 \mathrm{~g})$ and T8 (91.60 g) showed maximum leaf biomass in comparison to the other treatment combinations (Table 2). 
Table 2. Growth parameter of the castor plants supplemented with different Pseudomonas treatment combinations.

\begin{tabular}{|c|c|c|c|c|c|c|c|c|c|}
\hline Treatments & $\begin{array}{c}\text { No. of } \\
\text { leaves per } \\
\text { plant }\end{array}$ & $\begin{array}{l}\text { Fresh leaf } \\
\text { weight (g) }\end{array}$ & $\begin{array}{c}\text { Stem base } \\
\text { diameter } \\
\text { (cm) }\end{array}$ & $\begin{array}{c}\text { Root } \\
\text { length } \\
(\mathrm{cm})\end{array}$ & $\begin{array}{c}\text { Root } \\
\text { biomass } \\
\text { (g) }\end{array}$ & $\begin{array}{l}\text { Shoot } \\
\text { length } \\
(\mathrm{cm})\end{array}$ & $\begin{array}{c}\text { Leaf } \\
\text { biomass } \\
\text { (g) }\end{array}$ & $\begin{array}{c}\text { Leaf } \\
\text { moisture } \\
\text { content } \\
\text { (g) }\end{array}$ & $\begin{array}{c}\text { Percentage of } \\
\text { leaf biomass } \\
\text { increase over } \\
\text { control (\%) }\end{array}$ \\
\hline $\mathrm{T}_{1}$ (FYM-inorganic) & $42.80^{\circ *}$ & $291.50^{* *}$ & $3.56^{* *}$ & $41.80^{* *}$ & $48.10^{* *}$ & $240^{\mathrm{ns}}$ & $66.10^{* *}$ & $272.70^{\circ}$ & NA \\
\hline $\mathrm{T}_{2}$ (Cow-dung) & $43.70^{\circ *}$ & $357.00^{* *}$ & $3.08^{* *}$ & $35.50^{* *}$ & $43.00^{* *}$ & $216^{\mathrm{ns}}$ & $66.90^{\circ *}$ & $281.90^{\circ}$ & 01.21 \\
\hline $\mathrm{T}_{3}(50 \% \mathrm{FYM}+\mathrm{MAJ}$ PIA01) & $42.15^{* *}$ & $254.00^{* *}$ & $2.79^{* *}$ & $30.40^{* *}$ & $44.50^{* *}$ & $202^{\mathrm{ns}}$ & $74.50^{* *}$ & $232.80^{*}$ & 12.70 \\
\hline $\mathrm{T}_{4}(50 \%$ FYM + MAJ PIA02) & $42.23^{* *}$ & $305.00^{* *}$ & $2.20^{* *}$ & $54.90^{* *}$ & $46.70^{* *}$ & $172^{\mathrm{ns}}$ & $74.00^{* *}$ & $255.80^{\circ}$ & 14.97 \\
\hline $\mathrm{T}_{5}(50 \%$ FYM + MAJ PIA03) & $49.40^{\circ *}$ & $396.00^{* *}$ & $2.46^{* *}$ & $59.60^{* *}$ & $55.10^{* *}$ & $175^{\mathrm{ns}}$ & $97.60^{* *}$ & $354.90^{\circ}$ & 47.65 \\
\hline $\mathrm{T}_{6}(50 \%$ FYM + MAJ PIA 24$)$ & $38.56^{* *}$ & $321.00^{* *}$ & $3.94^{* *}$ & $57.20^{* *}$ & $49.30^{* *}$ & $260^{\mathrm{ns}}$ & $83.80^{* *}$ & $300.40^{\circ}$ & 26.77 \\
\hline $\mathrm{T}_{7}(50 \%$ FYM + MAJ PIA43) & $34.75^{* *}$ & $248.00^{* *}$ & $3.07^{* *}$ & $31.80^{* *}$ & $51.21^{* *}$ & $200^{\mathrm{ns}}$ & $82.40^{* *}$ & $231.80^{\circ}$ & 24.65 \\
\hline $\mathrm{T}_{8}(50 \%$ FYM + MAJ PIA66) & $31.69^{* *}$ & $219.00^{* *}$ & $3.24^{* *}$ & $51.80^{* *}$ & $42.00^{* *}$ & $229^{\mathrm{ns}}$ & $91.60^{* *}$ & $189.40^{\circ}$ & 38.57 \\
\hline T9 $(50 \%$ FYM + MAJ PIA 76$)$ & $44.92^{* *}$ & $330.00^{* *}$ & $2.17^{* *}$ & $40.40^{* *}$ & $37.86^{* *}$ & $236^{\mathrm{ns}}$ & $73.20^{* *}$ & $292.80^{\circ}$ & 10.74 \\
\hline $\mathrm{T}_{10}(50 \%$ FYM + MAJ PIA79) & $45.34^{* *}$ & $345.00^{* *}$ & $3.87^{* *}$ & $56.60^{* *}$ & $40.22^{* *}$ & $230^{\mathrm{ns}}$ & $60.40^{* *}$ & $325.60^{\circ}$ & -08.62 \\
\hline S. Em $( \pm)$ & 2.74 & 25.82 & 0.28 & 3.17 & 2.47 & 24 & 2.68 & 28.97 & - \\
\hline S. Ed $( \pm)$ & 3.87 & 36.52 & 0.40 & 4.49 & 3.49 & 35 & 3.79 & 40.98 & - \\
\hline C.D $5 \%( \pm)$ & 8.09 & 76.17 & 0.84 & 9.37 & 7.29 & 73 & 7.91 & 85.48 & - \\
\hline
\end{tabular}

*NA: Not applicable, S. Em: Standard Error Mean, S. Ed: Standard Error Deviation, C. D: Critical Difference, **:p < 0.05, *:p $<0.01$ and ns: non-significant

\subsection{Leaf biochemical characterization}

Among the five essential leaf biochemical components, total carbohydrate $(33.16 \pm 0.85 \%)$, phenol $(25.81 \pm 0.45 \%)$ and lipid $(25.52 \pm 1.13 \%)$ content was found maximum in the leaf samples of treatment T5 (Figure $3 \&$ 4). Similarly, protein $(16.04 \pm 0.65$ $\%$ ) content was highest in $\mathrm{T} 6$, which has been followed by T5 $(15.09 \pm 0.64 \%)$. Moreover, T5 enhanced theChlorophyll 'a' $(24.87 \pm 0.77 \mathrm{mg} / \mathrm{g}$ tissue), chlorophyll 'b' (20.53 $\pm 0.72 \mathrm{mg} / \mathrm{g}$ tissue $)$ and total chlorophyll $(20.15 \pm 1.17 \mathrm{mg} / \mathrm{g}$ tissue) contents of castor plant over other treatments (Figure 5). Nitrogen content and crude fiber content was estimated highest in $\mathrm{T}_{8}(1.96 \pm 0.07 \%)$ and $\mathrm{T}_{5}(9.78 \pm 0.71 \%)$, respectively which has been followed by $\mathrm{T}_{6}(1.86 \pm$ $0.07 \%$ and $8.85 \pm 0.06 \%$ ) (Figure 6).

\subsection{Molecular identification}

Based on the above results, the most efficient Pseudomonas isolate MAJ PIA03 was identified upto species level through, morphological, biochemical (Table 3) and 16S rRNA gene homology. The 16S rDNA sequence has been obtained through the courtesy to Merck Milipore (Bangalore Genei), Bangalore, India. The sequence has been aligned with the closest homology by using the BLAST tool of NCBI (National Centre for Biotechnology Information). The phylogenetic tree showed closest homology of the strain with Pseudomonas aeruginosa NBRC 12689 and hence identified as Pseudomonas aeruginosa strain MAJ PIA03 (Figure 7). The 16S rDNA sequence was submitted to NCBI and obtained the accession no. KM875456. 


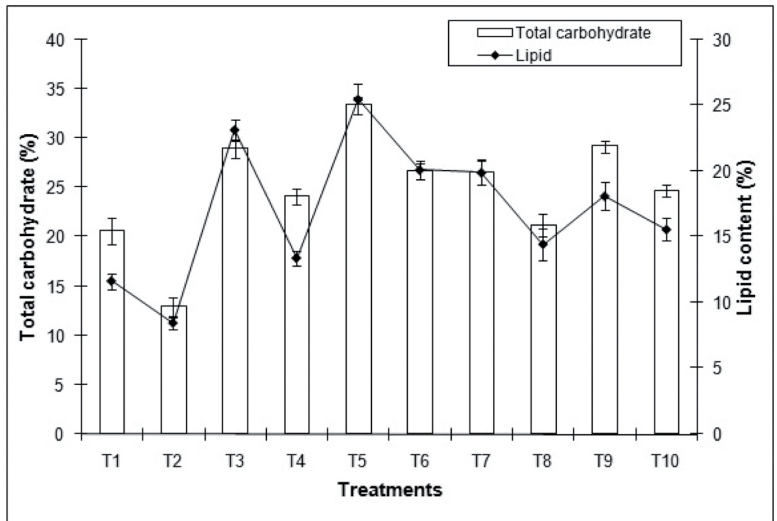

Figure 3. Total carbohydrate and lipid content (\%) of castor leaf treated with Pseudomonas isolates.

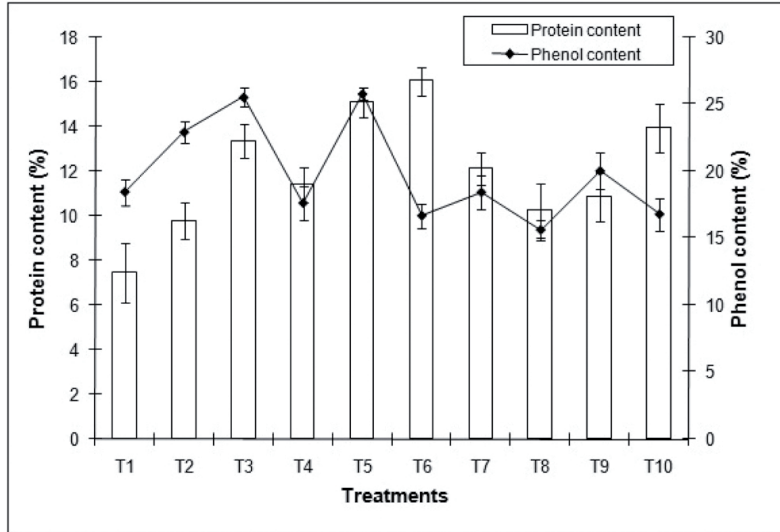

Figure 4. Protein and phenol content (\%) of castor leaf treated with Pseudomonas isolates.

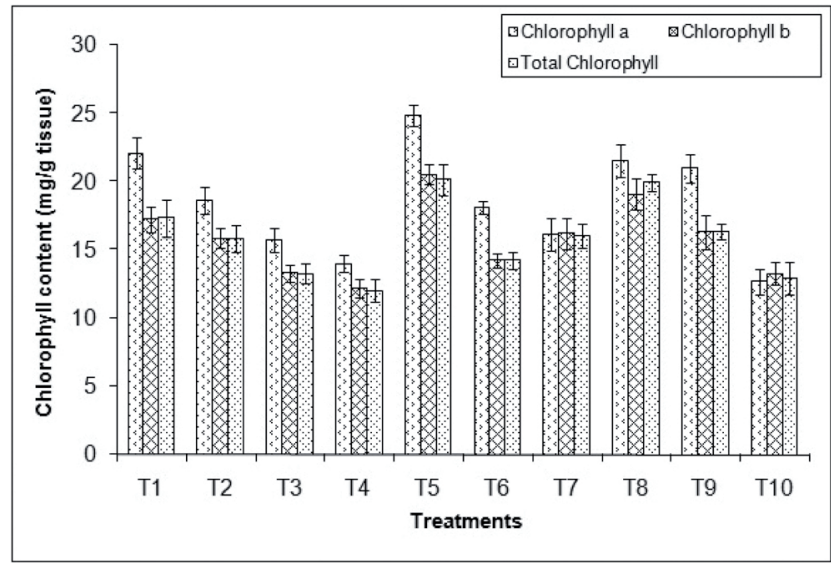

Figure 5. Chlorophyll content (mg/g tissue) of castor leaf treated with Pseudomonas isolates. 


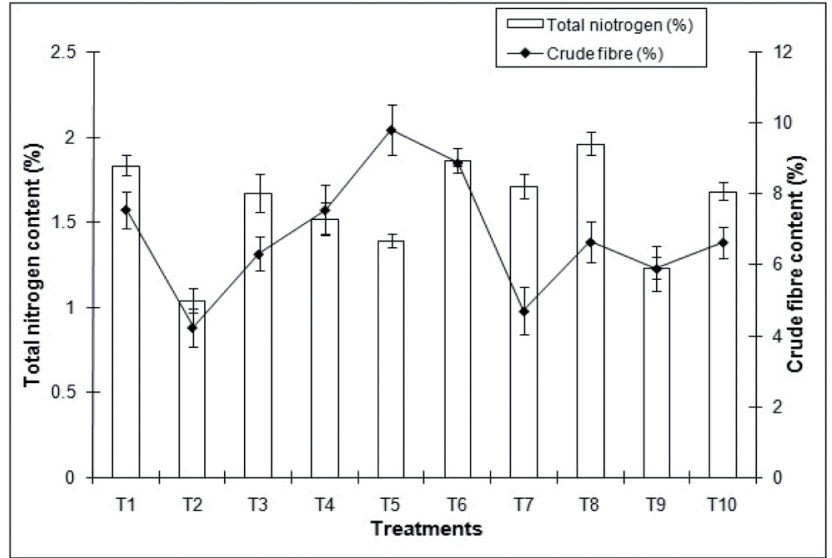

Figure 6. Nitrogen and crude fiber content (\%) of castor leaf treated with Pseudomonas isolates

Table 3. Morphological and biochemical characterization of the Pseudomonas aeruginosa MAJ PIA03

\begin{tabular}{lclc}
\hline Characteristic features & Result & Characteristic features & Result \\
\hline Gram reaction & Negative & Sugar utilization test & \\
Morphology & Rod & Glucose & + \\
Methyl red test & + & Sucrose & + \\
Indole test & - & Lactose & - \\
Citrate utilization & + & Fructose & + \\
Catalase test & + & Mannitol & + \\
Nitrate reductase & + & Arabinose & - \\
Voges Proskeur & - & Trehalose & - \\
ONPG & - & Sorbitol & - \\
Gelatin liquefaction & + & Adonitol & - \\
Phenylalanine & - & Cellobiose & - \\
Starch hydrolysis & - & Iso-propanol & - \\
H2S production & - & Maltose & - \\
Arginine & + & Methanol & - \\
Ornithine & + & Galactose & - \\
Succinate & + & Mannose & - \\
Starch & - & Rhamnose & - \\
Tryptophan & - & Xylose & - \\
Urease & + & & \\
Oxidase & + & & \\
Lipase & + & & \\
Alanine & + & & \\
Lactate & + & & \\
Malate & + & & \\
Gluconate & + & & \\
Glycerate & + & & \\
Malonate & + & & \\
Benzylamine & - & & \\
\hline
\end{tabular}

* ‘+’: Positive activity, '-’: Negative activity 


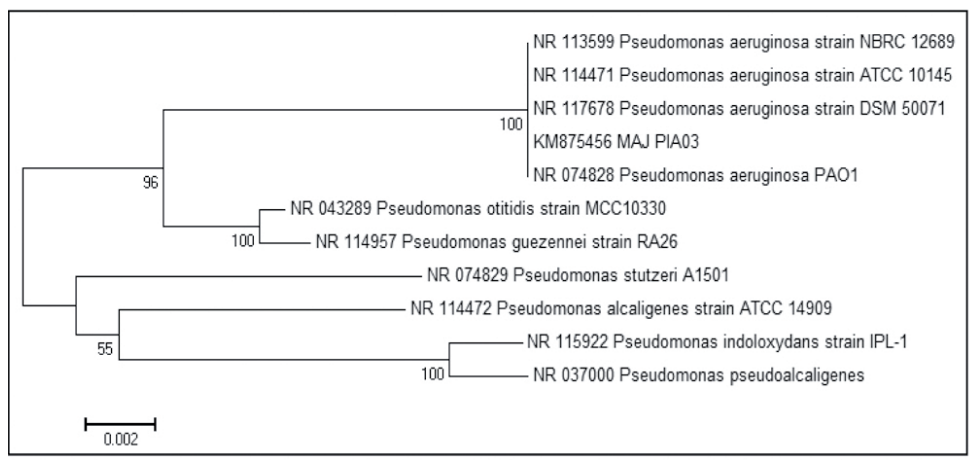

Figure 7. Phylogenetic tree-based on the $16 \mathrm{~S}$ rDNA sequence indicating the position of strain MAJ PIA03 (using Neighbor Joining method).

\section{Discussion}

Pseudomonads are the first commercially used microbes isolated from soil as a biological means of plant growth promotion (Reed and Glick 2004). In this study, out of all Pseudomonads, isolate no. MAJ PIA03 produced highest amount of IAA, GA3 and ACC deaminase in vitro. Most of them have synthesized some agriculturally important compounds such as $\mathrm{HCN}, \mathrm{NH}_{3}$, siderophore, antifungal agents, etc. and can be utilized in sustainable castor cultivation in ericulture. Bholay et al. (2012) observed biosynthesis of pyoverdin by Pseudomonas aeruginosa which acts as a siderophore. PGPR produce $\mathrm{NH}_{3}, \mathrm{HCN}$ and Siderophore which enhance nitrogen accumulation, plant biomass and some important traits such as root and shoots elongation in agricultural crops (Marques et al., 2010). Kumar et al. (2012) reported on production of IAA by Pseudomonas sp. FBK3 (21.31 mg/L), which is slightly lower than Pseudomonas sp. MAJ PIA03 (27.84 mg/L), used in this study. Inoculation of other PGPR such as Bacillus sp. OSU142 and Bacillus sp.M3 in sugar beet, barley corn (Ataoglu et al., 2004) and tomato (Turan et al., 2004) stimulated various growth parameters. Similarly, application of Bacillus sp.WG4 effectively protect ginger rhi- zomes from being attacked by Pythium myriotylum by secreting antifungal metabolite pyrrolo [1, 2-a] pyrazine-1, 4-dione, hexahydro-3-(phenylmethyl) (Jimtha et al., 2016).

In-vitro results of PGPR species may not be always reproduced under field, semi-field or even greenhouse conditions as the interaction between the associative PGPR and plants could be unstable (Marques et al., 2010; Zhender et al., 1999). They further stated that, performance of PGPR is directly correlated to different environmental conditions along with the soil characteristics. This study established the efficiency of the Pseudomonads prevalent to castor rhizosphere by enhancing up to $47.65 \%$ of leaf biomass over control under field condition. Marques et al. (2010) reported that Sphingobacterium sp. 1ZP4, Bacillus sp., Achromobacter sp. and Ralstonia $\mathrm{sp}_{1 \mathrm{C}_{2}}$ influence on root, shoot elongation and biomass production of Zea mays in greenhouse condition. Similarly, Pseudomonas putida, Azospirilum lipoferum, Gluconacetobacter azotocaptans, Azospirillum zeae and Azospirillum canadense were reported to enhance growth of agricultural crops by synthesizing PGP agents (Mehnaz 2007b). Firmicute strain Bacillus subtilis (Araujo 2008) is an efficient plant growth promoter in Zea mays and highly effective against tomato wilt disease. 
Leaf biomass and growth was enhanced significantly, in plants treated with Pseudomonas sp. MAJ PIA03 and $50 \%$ supplementary NPK over recommended dose. Application of native Pseudomonads on castor plant as PGPR may induce systemic resistance against soil born diseases. Leaf biomass and stem diameter was also increased by applying Pseudomonas fluorescence Pf5 in high bush blue berry (De Silva et al., 2000).

Moderate range of phenol content was found in leaves treated with $\mathrm{T}_{5}$, however, high phenol content affects on the feeding efficiency of silkworm (Rao et al., 2009). Total phenol content and insect resistance have a positive association with each other where the former plays a crucial role in plant defence mechanism against entomo-pathogens (Anjani et al., 2010). Larval weight and cocoon weight are influenced by the nitrogen and crude protein content of castor leaves (Sarmah et al., 2011). Besides, Akhtar et al. (2011) observed significant rise of chlorophyll content and other growth parameter such as shoot length, root length, shoot fresh and dry weights, root fresh and dry weights and number of nodules per plant in $P$. fluorescence treated plants against control. Prathibha and Siddalingeshwara (2013), noticed augmentation of total carbohydrate and total soluble protein content during application of Bacillus subtilis, $P$. fluorescence on seeds of sorghum plant. Application of $\mathrm{NO}_{3}{ }^{-}, \mathrm{NH}_{4}^{+}$or $\mathrm{NO}_{3} \mathrm{NH}_{4}$ singly or in combination with PGPR inoculation led to a significant increase in root dry weight, shoot dry weight, leaf number, shoot length, stem base diameter, crude fiber and nutrient uptake (Tchiaze et al., 2016).

This study reflects the role of native Pseudomonas on castor plant as PGPR on upgrading the nutritional quality of leaf. Leaf nutritional components viz. carbohydrate, protein, lipid, fat, chlorophylls, fiber etc., play significant role on growth and productivity of S. ricini.

\section{Conclusions}

The sericulture farmers of Northeast India use considerably large amount of inorganic fertilizer to replenish soil $\mathrm{N}, \mathrm{P}$ and $\mathrm{K}$ resulting high cost and increased environmental pollution. Inoculation with native Pseudomonads have significant contribution to agro-ecosystems by $\mathrm{N}_{2}$ fixation, P-solubilization, synthesis of biocontrol agent and PGP compounds such as IAA, GA3, ACC deaminase, $\mathrm{NH}_{3}$ etc. Although, numerous Pseudomonas species have been isolated till date from different agricultural localities but using native rhizosphere isolates is an added advantage for better adaptation. Application of Pseudomonas aeruginosa MAJ PIA03 with 50\% restrain on inorganic NPK dose promoted root biomass by $12.70 \%$ and leaf biomass by $32.27 \%$ over control. The phytochemical constituents such as total chlorophyll, protein, carbohydrate, crude fiber and lipid content were increased in castor leaf while treated with Pseudomonas aeruginosa MAJ PIA03. Bioformulation of P. aeruginosa MAJ PIA03 with reduced inorganic NPK can be a potential INM package in future for sustainable cultivation of R. communis for eri sericulture industry.

\section{Acknowledgements}

The authors are grateful to the Director, Central Muga Eri Research \& Training Institute (CMER\&TI), Central Silk Board, Lahdoigarh, Jorhat, Assam (India) for providing the necessary facilities and Department of Science \& Technology, Govt. of India, New Delhi (India) for providing the fund to conduct the work. 


\section{References}

Akhtar, A., Hisamuddin, A., Sharf, R. 2011. Antagonistic effects of Pseudomonas fluorescens and $\mathrm{Ba}$ cillus subtilis on Meloidogyne incognita infecting Vigna mungo 1. International Journal of Plant, Animal and Environmental Sciences. 2, 55- 63.

Anjani, K., Pallavi, M., Babu, S.N.S. 2010. Biochemical basis of resistance to leaf miner in castor (Ricinus communis L.). Ind. Crop Prod. 31, 192-196.

Araujo, F.F. 2008. Seed inoculation with Bacillus subtilis formulated with oyster meal and growth of corn, soybean and cotton. Ciencia Agrotecnologia Lavras. 32, 456-462.

Arnon, D.I. 1949. Copper enzymes in isolated chloroplasts: Polyphenoloxidase in Beta vulgaris. Plant Physiology. 24(1), 1-16.

Ataoglu, N., Turan, M., Sezen, Y. 2004. Effects of phosphorus solubilizing bacteria (Bacillus megatherium) and growing media on growing performance and mineral contents of corn plant (Zea mays L.). In: Proceedings of the International Soil Congress on Natural Resource Management for Sustainable Development, Erzurum, Turkey, 7-10 June, 2004. pp. 10-18.

Bholay, A.D., Jadhav, P.U., Borkhataria, B.V., Dhalkari, M.V. 2012. Fluorescent Pseudomonads as plant growth promoting rhizobacteria and their siderophorogenesis. IOSR J. Pharm. Biol. Sci. 3, 27-32.

Bordoloi, G., Kumari, B., Guha, A., Bordoloi, M.J., Yadav, R.N.S., Roy, M.K., Bora, T.C. 2001. Isolation and structure elucidation of a new antifungal and antibacterial antibiotic produced by Streptomyces sp. 201. Biosci. Biotech. Biochem. 65, 1856-1858.

Buchanan, R.E., Gibbons, N.E. 1974. Bergey's Manual of Determinative Bacteriology. 8th ed. Baltimore, USA.
Cappuccino, J.C., Sherman, N. 1992. Negative staining. In: Cappuccino, J.C., Sherman, N. (Eds.), Microbiology: A Laboratory Manual, third ed. Benjamin/ Cummings Pub Co, Redwood City. P. 125-179.

De Silva, A., Moore, J., Patterson, K. 2000. Growth promotion of high bush blueberry by fungal and bacterial inoculants. Hort. Sci. 35, 1228.

Dwivedi, D., Johri, B.N. 2003. Antifungals from fluorescent pseudomonads: biosynthesis and regulation. Curr. Sci. 12, 1693-1703.

Esitken, A., Ercisli, S., Karlidag, H., Sahin, F. 2005. Potential use of plant growth promoting rhizobacteria (PGPR) in organic apricot production. In: Proceedings of the International Scientific Conference of Environmentally Friendly Fruit Growing, Tartu-Estonia, 7-9 September. P. 9097.

Glick, B.R., Lucy, M., Reed, E. 2004. Application of free living plant growth promoting rhizobacteria. Antonie Van Leeuwenhoek. 86, 1.

Grammer, A. 1976. Antibiotic sensitivity and Assay test. In: Microbiological Methods, Collins, C. H., Lyne, P.M. (ed). Butterworths, London. P. 235.

Holt, J.G., Krieg, N.R., Sneath, P.H., A, Staley. 1994. Bergey's Manual of Determinative Bacteriology, 9th (ed). Williams \& Wilkins, Baltimore, USA. P. 175.

Honma, M., Shimomura, T. 1978. Metabolism of 1-aminocyclopropane-1-carboxylic acid. Agriculture Biology and Chemistry. 42, 1825-1831.

Jimtha J.C., Jishma P., Arathy G.B., Anisha C., Radhakrishnan, E. K. 2016. Identification of plant growth promoting Rhizosphere Bacillus sp. WG4 antagonistic to Pythium myriotylum and its enhanced antifungal effect in association with Trichoderma. Journal of Soil Science and Plant Nutrition. 16 (3), 578-590. 
Kumar, A., Kumar, A., Devi, S., Patil, S., Chandani, P., Nagi, S. 2012. Isolation, screening and characterization of bacteria from rhizospheric soils from different plant growth promotion activities: as in vitro study. Recent research in science and technology. 4,1 .

Lind, K., Lafer, G., Schloffer, K., Innerhoffer, G., Meister, H. 2003. Organic Fruit Growing. CABI Publishing, Wallingford, UK.

Lorck, H. 1948. Production of hydrocyanic acid by bacteria. Physiol Plant. 1, 142-146.

Lowry, O. H., Rosebrough, N. J., Farr, A. L., Randall, R. J. 1951. Protein measurement with folin reagent. J Biol Chem. 193, 265-275.

Marmur, J. 1961. A procedure for the isolation of deoxyribonucleic acid from microorganisms. J Mol Biol. 3, 208.

Marques, A.P.G.C., Pires, C., Moreira, H., Rangel, A.O.S.S., Castro, P.M.L. 2010. Assessment of the plant growth promotion abilities using Zea mays as indicator plant. Soil Biology and Biochemistry. $42,1229$.

Mehnaz, S., Weselowski, B., Lazarovits, G. 2007b. Azospirillum zeae sp. nov., a diazotrophic bacteria isolated from rhizosphere soil of Zea mays. Journal of Systematic and Evolutionary Microbiology. 57, 2805-2809.

Paleg, L.G. 1965. Physiological effects of gibberellins. Ann Rev Plant Physiol. 16, 291.

Prathibha, K.S., Siddalingeshwara, K.G. 2013. Effect of plant growth promoting Bacillus subtilis and Pseudomonas fluorescence as Rhizobacteria on seed quality of sorghum, Int. J. Curr. Microbiol. App. Sci. 2, 11-18.

Price, M., Butler, L.G. 1977. Rapid visual estimation and spectrophotometric determination of tannin content of sorghum grain. J. Agric. Food Chem. $55,1268-1273$.
Rao, S.C., Northup, B. K. 2009. Capabilities of four novel warm-season legumes in the southern Great Plains: grain production and quality. Crop Science. $49,1103-1108$.

Reed, M.L.E., Glick, B.R. 2004. Applications of free living plant growth-promoting rhizobacteria. Anton Van Leeuwenhoek. 86, 1-25.

Sadasivam, S., Manickam, A. 2005. Biochemical Methods. Newage International Pvt. Limited, New Delhi.

Saitou, N., Nie, M. 1987. The Neighbour-joining method: a new method for reconstructing phylogenetic trees. Mol. Biol. Evol. 4, 406.

Sandilya, S.P., Bhuyan, P.M., Gogoi, D.K., Kardong, D. 2016. Phosphorus Solubilization and Plant Growth Promotion Ability of Rhizobacteria of $R$. communis L Growing in Assam, India. Proc. Natl. Acad. Sci., India, Sect. B. Biol. Sci. doi: 10.1007/ s40011-016-0833-9.

Sarmah, M.C, Chutia, M., Neog, K., Das, R., Rajkhowa, G., Gogoi, S.N. 2011. Evaluation of promising castor genotype in terms of agronomical and yield attributing traits, biochemical properties and rearing performance of eri silkworm, Samia ricini (Donovan) Ind. Crop Prod. 31, 192-196.

Schwyn, B., Neilands, J.B. 1987. Universal chemical assay for the detection and determination of siderophores. Analytical Biochemistry. 160, 47-56.

Sirohi, G., Upadhyay, A., Srivastava, P.S., Srivastava, S. 2015. PGPR mediated Zinc biofertilization of soil and its impact on growth and productivity of wheat. Journal of Soil Science and Plant Nutrition. 15(1), 202-216.

Tchiaze, A.I., Taffouo, V.D., Fankem, H., Kenne, M., Baziramakenga, R., Ekodeck, G.E., Antoun, H. 2016. Influence of Nitrogen Sources and Plant Growth-Promoting Rhizobacteria Inoculation on Growth, Crude Fiber and Nutrient Uptake in 
Squash (Cucurbita moschata Duchesne ex Poir.) Plants. Not. Bot. Horti. Agrobio. 44, 53-59.

Turan, M., Ataoglu, N., Sezen, Y. 2004. Effects of phosphorus solubilizing bacteria (Bacillus megaterium) on yield and phosphorus contents of tomato plant (Lycopersicon esculentum L.) III. In: Proceedings of the National Fertilizer Congress. Farming-Industry-Environment, Tokat, Turkey, 11-13 October.

Viscardi, S., Ventorino V., Duran, P., Maggio, A., De Pascale, S., Mora, M.L., Pepe, O. 2016. Assessment of plant growth promoting activities and abiotic stress tolerance of Azotobacter chroococcum strains for a potential use in sustainable agriculture. Journal of Soil Science and Plant Nutrition, 16(3), 848-863.

Weisberg, W.G., Barns, S.M., Pelletier, B.A, Lane, D. J. 1991. 16S ribosomal DNA amplification for phylogenetic study. J. Bacteriol. 173, 697.
Weller, D.M. 2007. Pseudomonas biocontrol agents of soil borne pathogens: Looking back over 30years. Phytopathology. 97, 250-256.

Wohler, I. 1997. Auxin-indole derivatives in soils determined by a colorimetric method and by high performance liquid chromatography. Microbiological Research. 152, 399.

Zhender, G.W., Yao, C., Murphy, J.F., Sikora, E.R., Kloepper, J.W, Schuster, D.J., Polston, J.E. 1999. Microbe-induced resistance against pathogens and herbivores: evidence of effectiveness in agriculture. In: Agarwal, A.A., Tuzun, S., Bent., E. (ed). Induced Plant Defenses against Pathogens and Herbivores: Biochemistry, Ecology and Agriculture. APS Press, St. Paul, MN, P. 33. 